\title{
Professional qualification in the School Health Program from the perspective of Complexity Theory
}

\author{
Capacitação profissional no Programa Saúde na Escola sob a perspectiva da Teoria da Complexidade \\ Capacitación profesional en el Programa Salud en la Escuela conforme la perspectiva de la Teoría de la \\ Complejidad
}

Eliabe Rodrigues de Medeiros ${ }^{1}$ (1) Alexsandra Rodrigues Feijão ${ }^{1}$ (i) Erika Simone Galvão Pinto ${ }^{1}$ (1) Viviane Euzébia Pereira Santos ${ }^{1}$ (D)

Universidade Federal do Rio Grande do Norte. Natal, RN, Brasil.

\begin{abstract}
Objective: To reflect on the qualification process of the professionals of the School Health Program through the Complexity Theory. Method: Edgar Morin's theoretical framework was used to defend the need to overcome the reductionist, disjunctive and limiting view of thought through the integration of knowledge. The recursive, dialogic and hologramatic principles and the concepts of order and disorder supported this process. Results: It was understood that the products and effects are included in the same process and if they are retroactive. The interaction and dialogue between the different professionals through the union of different ideas are necessary and become inseparable for the complexity of the capacities, when not only the parts are in the whole, but the whole is also identified in the parts. Conclusion and implications for the practice: It is necessary to integrate health and education professionals in the training of the School Health Program when considering their needs in the work processes, when counting on the contribution of the knowledge of other disciplines and sectors, as well as when sharing attributions in the execution of the activities proposed by the School Health Program.
\end{abstract}

Keywords: Philosophy, Nursing; School Health Services; Professional Training; Intersectoral Collaboration.

\section{REsUmo}

Objetivo: Refletir sobre o processo de capacitação dos profissionais do Programa Saúde na Escola mediante a Teoria da Complexidade. Método: Utilizou-se o referencial teórico de Edgar Morin que defende a necessidade de sobrepor a visão reducionista, disjuntiva e limitadora do pensamento mediante a integração de saberes. Os princípios recursivo, dialógico e hologramático e os conceitos de ordem e desordem subsidiaram esse processo. Resultados: Compreendeu-se que os produtos e os efeitos estão incluídos em um mesmo processo e se retroagem. A interação e o diálogo entre os diferentes profissionais mediante a união de ideias distintas são necessárias e torna-se indissociável para a complexidade das capacitações, quando não apenas as partes encontram-se no todo, mas o todo é também identificado nas partes. Conclusão e implicações para a prática: É necessário integrar profissionais de saúde e educação nas capacitações do Programa Saúde na Escola ao considerar suas necessidades nos processos de trabalho, contar com a contribuição dos saberes de outras disciplinas e setores, bem como compartilhar atribuições na execução das atividades propostas pelo Programa Saúde na Escola.

Palavras-chave: Filosofia em Enfermagem; Serviços de Saúde Escolar; Capacitação Profissional; Colaboração Intersetorial.

\section{Resumen}

Objetivo: Reflexionar sobre el proceso de capacitación de los profesionales del Programa Salud en la Escuela conforme la Teoría de la Complejidad. Método: Se utilizó el referencial teórico de Edgar Morin que defiende la necesidad de sobreponerse a la visión reduccionista, disyuntiva y limitadora del pensamiento mediante la integración de saberes. Los principios recursivo, dialógico y hologramático y los conceptos de orden y desorden subsidiaron este proceso. Resultados: Se comprendió que los productos y los efectos están incluidos en un mismo proceso y se retrotraen. Hay la necesidad de la interacción y el diálogo entre los diferentes profesionales mediante la unión de distintas ideas, siendo indisociables para la complejidad de las capacitaciones, cuando no solo las partes se encuentran en el todo, sino que también el todo se identifica en las partes. Conclusión e implicaciones para la práctica: Es necesario integrar los profesionales de la salud y los de la educación en las capacitaciones del Programa Salud en la Escuela considerando sus necesidades en los procesos de trabajo, contar con la contribución de los saberes de otras disciplinas y sectores, además de repartir las atribuciones al ejecutar las actividades propuestas por el Programa Salud en la Escuela.

Palabras clave: Filosofía en Enfermería; Servicios de Salud Escolar; Capacitación Profesional; Colaboración Intersectorial.
Corresponding author:

Eliabe Rodrigues de Medeiros.

E-mail: eliabe.medeiros@hotmail.com

Submitted on 02/11/2019.

Accepted on 04/26/2019.

DOI: 10.1590/2177-9465-EAN-2019-0035 


\section{INTRODUCTION}

The promotion of health at school has a philosophy that aims at improving the quality of life and the wellbeing of students and professionals involved in this space. It is possible to promote health through the use of collective and individual approaches directed to the school community. Its effects can be observed by optimizing the health, educational and social characteristics. ${ }^{1}$

This perspective was initially proposed by the World Health Organization in the 1980s and 1990s from the launch of the Health Promoting Schools Initiative. ${ }^{2}$ Several nations have been influenced and currently carry out interventions with different themes in the school environment, such as physical activity and healthy eating, prevention of drug use and attention to chronic and infectious diseases. ${ }^{3}$

Several nations have been influenced and currently carry out interventions with different themes in the school environment, such as physical activity and healthy eating, prevention of drug use and attention to chronic and infectious diseases. ${ }^{4}$

The actions proposed by the Health Program in the School are organized in three components that have equal importance in its execution. In the first one, there are activities of evaluation of the health conditions in a clinical and psychosocial character, as the ophthalmological and anthropometric evaluation. The activities of health promotion and prevention of diseases and diseases are included in the second component, such as activities to promote sexual and reproductive health and prevention of sexually transmitted infections/Aids, as well as activities to prevent the use of alcohol, tobacco, crack and other drugs. The activities of professional training and continuing education are part of the third component and refer to training for professionals on the themes to be implemented. .,6 $^{5}$

The implementation of the latter must take place on a continuous and permanent basis in search of teachers and health professionals who have the support to plan and carry out the activities proposed by the program. ${ }^{7}$ To this end, it is hoped that the interinstitutional and inter-sectoral articulations will be established as recommended by the National Policy on Permanent Education in Health ${ }^{8}$ in the planning and execution of these capacities, in order to foster the improvement of school health practices.

Even with this expectation, research indicates their qualifications or absence as important difficulties for the execution of the Health Program in the School. ${ }^{9}$ It is identified that these trainings are carried out in a timely and isolated manner ${ }^{10}$ by different professionals, and there is a need to review these training processes for the professionals who work in the program. $^{11}$

These aspects refer to the execution of activities fragmented by professionals of different backgrounds and are treated by
Edgar Morin ${ }^{12}$ as a simplistic model of thinking. On the other hand, the author presents the need not to restrict himself to this way of thinking and to seek the perspective of complexity.

Due to the understanding that many of these gaps in the training of the School Health Program cannot be understood by the simplistic model of thought, the following question has arisen: how can the School Health Program qualifications be carried out from the perspective of Complexity Theory?

In order to respond to this questioning, the objective is to reflect on the qualification process of the professionals of the Health Program in the School through the Complexity Theory.

\section{COMPLEXITY THEORY AND SKILLS OF THE SCHOOL HEALTH PROGRAM}

The Complexity Theory is presented by Morin ${ }^{12}$ in order to overcome the reductionist, disjunctive and limiting view of thought. Therefore, the aggregation of the values of phenomena is proposed through the union of multidisciplinary and multidimensional perspectives and the holding of the essence of this theory in incompleteness and uncertainty.

For the philosopher, simplistic views of thinking happen when phenomena are subjected to principles and guidelines that seek to organize them, but they eventually mutilate and limit the nature of things. Based on the consequences that this reductionist view brings to the real world, complex thinking was structured in a perspective that transposes simplistic thinking and encompasses parts that could not be accepted. ${ }^{12}$

The term complexus is interpreted as a common tissue, consisting of parts closely integrated, inseparable and dependent on one another, to form a single object. The philosopher argues that the reintegration of what is separated is necessary to allow certainty and uncertainty to interact in the pursuit of a common goal. ${ }^{12}$

In order to understand the relationship of Complexity Theory to the capabilities of the School Health Program, the three basic principles of this theory (recursive, dialogic and hologramatic) and the necessary approximations between them are listed.

The recursive principle proposes the rupture of linearity in learning and advocates that the products and effects are themselves causative and created in this process of causation. ${ }^{12}$

In analyzing this principle it is possible to rationalize that the qualifications of the School Health Program should be proposed based on the needs presented by health and education professionals in their work processes, as well as the community ${ }^{13}$. It is, therefore, a learning process that considers different perspectives for the improvement of school health actions. When this happens, the doubts and needs are solved and the product of intersectoral collaboration, not only in the capacities, but also in the execution of the activities of the program, generates new requirements. 
This aspect reinforces the need for interaction between health and education professionals in the training programs of the School Health Program. It is from this need that the results expected by these formations can be reached, since there is a mutual process of interaction, this being the product of the participants in the formations.

The multiprofessional team of the health sector seeks results that provide the quality of life for the community. In the School Health Program, this multiprofessional team needs to contemplate, in its work, aspects that reinforce an interprofessional perspective with the participation of different professionals, through the complementation of shared knowledge and attributions in this process. ${ }^{9}$

Interprofessional collaboration is an important strategy in the execution of health activities in schools. Through it, it is possible to articulate knowledge and experiences that are seen as potentialities for establishing bond, co-responsibility and co-management of school health practices. ${ }^{14}$ These results can also be identified when the integration of these professionals in the training is advocated by providing positive effects from the planning process to the execution of the activities.

In the dialogical principle one has the inseparability of ideas and the need to relate logics and notions, which in some cases are antagonistic and seem to oppose each other. At the same time they are inseparable, complementary and highlight an idea of conciliation of divergences. ${ }^{12}$

This aspect can be identified and approached in the capacities when it is necessary to prepare the professionals from the planning to the joint accomplishment of the actions. ${ }^{15}$ This is what is observed when it is recommended that the elaboration should be carried out by previous contact between health professionals and education, from the pedagogical aspects worked in the school. For this, the pedagogical practices are considered as an important tool that will contribute to this process of joint construction. ${ }^{16}$

When planned and implemented with the participation of professionals from both sectors and the community, the interventions that include knowledge of the health topics addressed by health professionals, pedagogical practices dominated by education professionals, and knowledge of the population are created, resulting in the integration of knowledge. ${ }^{9}$

Another important aspect to be related in this logic is the contribution of management in the training of the School Health Program. Several difficulties have been pointed out by the professionals who carry out the activities, such as the inadequate availability of material resources and structure, as well as the lack of incentive on the part of the management. ${ }^{9}$ These characteristics denote that this contribution has been one of the challenges of the program; however, it is necessary to integrate these subjects in this process in order to contribute with the training and health activities directed to the school.
In this movement of exchanges we include the perspective of interdisciplinarity, which is understood as a means of exchanging knowledge among professionals of different disciplines in an integral and resolutive way, aiming at articulating knowledge and practices that contribute to a certain intervention by the democratic sharing of responsibilities and capacities by driving transformations in different senses of human relations. ${ }^{17}$

Therefore, the training of the School Health Program is a stage of complex relationships, in which the need for interactivity and interdependence among people is recognized. In this space there must be professional articulation and integration of the different visions involved with the opportunity to exchange experiences, cooperation and competence.

Intersectoriality is another important aspect of the School Health Program and can be understood through the principle of dialogic. His proposal has the view that an isolated sector cannot give resolution to the complex needs raised by society. In the case of the school context, the emergence of problems that interfere in this community requires different looks and the participation of several social sectors that contribute to the educational process of children and adolescents. ${ }^{18}$

In this program, the two main sectors responsible are health and education, but this intersectoral articulation should cover other instances of society, such as social assistance..$^{7,18}$ Thinking about the importance of the institutions and agents that are involved in them is necessary for the professionals who participate in the training, mainly because they are part of the main sectors involved and related in the execution of the Health Program in the School.

To deal with aspects regarding to the development of this interaction process should be carried out even at the moment of preparation to operationalize the program may be fundamental to seek effective strategies.

The hologramatic principle emphasizes the understanding that the parts represent the whole, but that the whole is also inserted in the parts. Each part is singular and has fundamental aspects that must be taken into consideration in the whole. This aspect suppresses reductionist and Cartesian thinking and understands that understanding the parts and the whole is possible through a constant movement. ${ }^{12}$

When this principle is related to the qualifications of the School Health Program, it is understood that it is necessary to consider menus that focus not only on the various themes necessary to be executed in the program, but also focus on the constitution of the program, including its norms, guidelines, principles and other aspects that help guide the performance of professionals.

It is important to conduct the training in this sense since the professionals who carry out the activities in the School Health Program are unaware of fundamental aspects regarding the dynamics of its functioning and even its attributions in this 
scenario. ${ }^{19}$ When they do not know how these activities are to be carried out, their performance becomes limited in the spectrum of possibilities offered by the intervention.

The topics are comprehensive and include, among others, anthropometric evaluation, ophthalmological evaluation, oral health evaluation, prevention regarding the use of alcohol, tobacco, crack and other drugs, promotion of sexual and reproductive health, and prevention of sexually transmitted infections/Aids. ${ }^{5}$ For this reason, this program is considered as a policy that requires the contribution of professionals from different areas to carry out the proposed activities, making it essential to multiprofessional work.

In the health sector, this performance includes the professionals of the Family Health Strategy, made up of doctors, nurses, nursing technicians, community health agents, dentists and auxiliary or dental health technicians. ${ }^{20}$ For the participation of professionals in the education sector, there are the teachers and pedagogical coordinators. ${ }^{11}$

It is essential that throughout the training, aspects such as the development of the actions of the program by the multiprofessional team are emphasized, which requires the contribution of all members of the teams in any of the activities, not only in the subject matter related to their profession.

All these conceptions are rooted in Morin's propositions ${ }^{21}$ by emphasizing the concern to gather, contextualize and globalize information and knowledge, as well as to show that these are essential in the search for overcoming segmentary and simplistic knowledge and in perfecting a process of complex formation capable of generating relevant knowledge. This will lead to complex thinking.
The interpretation of the elementary principles of complexity and its relation with the capabilities of the School Health Program allows us to understand that it is a phenomenon that comes from complementary relations that integrate and intercalate in the development of complex actions that provide effective results. These effects can be observed by the professionals acting in the search for a healthy educational process for the students.

The notion of complexity in Morin's view ${ }^{12}$ has also led to the introduction of the concepts of order and disorder as closely related to one another and interacting with the organization of the universe. Order is taken with the idea of organization that has interactions, interdependence and influence of internal and external factors. Disorder is considered as uncertainty and is the product of agitations, dispersions and instabilities.

For this, he proposed a tetragram composed of order, disorder, interaction and reorganization that together correspond to the universe. It is possible to infer that the various aspects approached about training are influenced by systems of order and disorder, which enable the interaction of aspects that were not related and, by interacting, contribute to the organization of the universe, in this case, the school universe and the health of its actors. This happens to contribute to the permanent organization and reorganization of school health training, as shown in Figure 1.

Tetragram allows understanding that the implementation of the Health Program in the School requires interdisciplinarity, multiprofessional action, interprofessionality and intersectoriality, fundamental points for the constitution of the program that are closely integrated and interdependent. It is through the understanding of what seems to be disorganized that one can have the organization of training.

Figure 1. Adaptation of the Morin Tetragram ${ }^{12}$ to the training programs of the School Health Program.

\section{Order}

\section{Disorder}

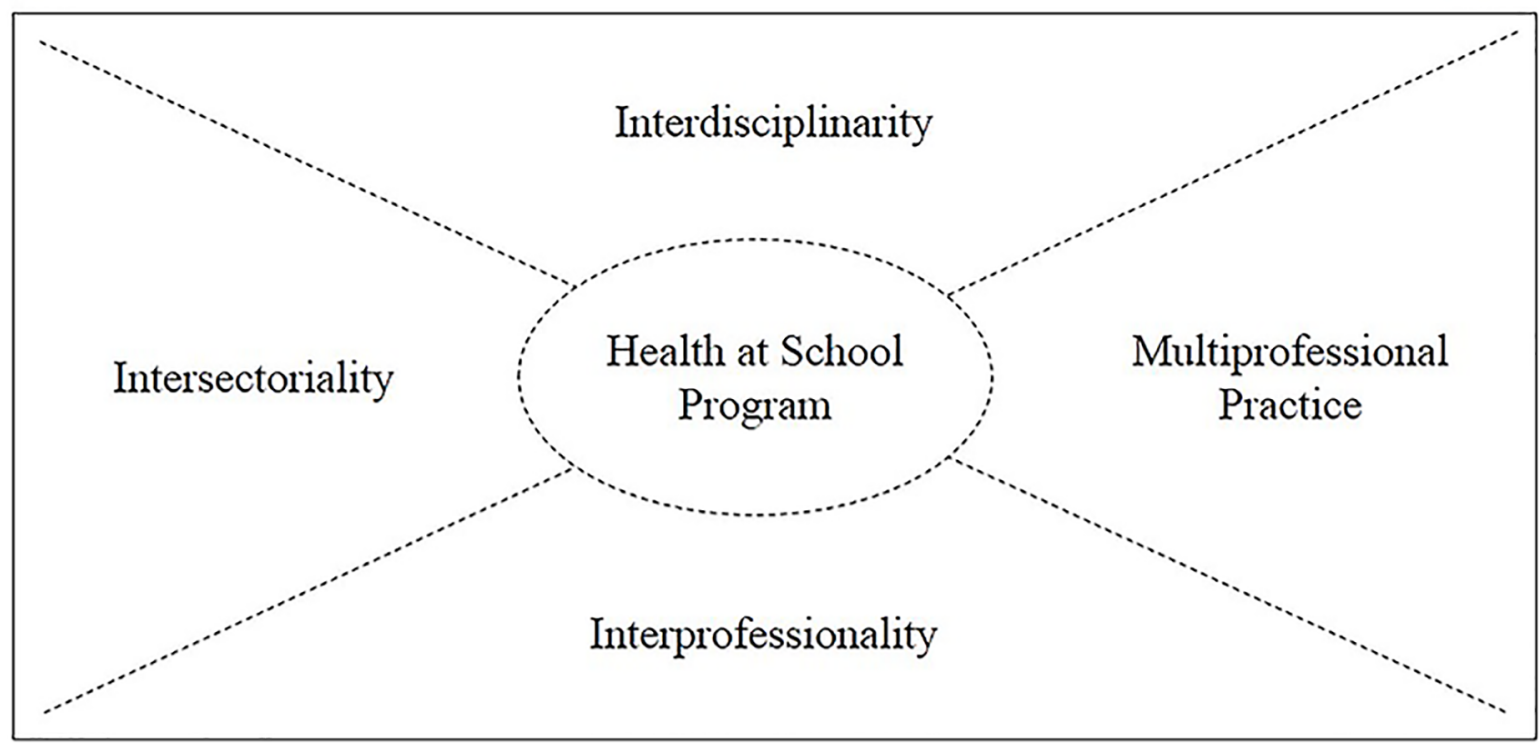

Interaction

Organization 


\section{FINAL CONSIDERATIONS AND IMPLICATIONS FOR PRACTICE}

From the Complexity Theory it was possible to reflect on how the training of health professionals and education in the School Health Program can be carried out. It was seen that complex processes are essential, which require the integration of professionals from different sectors of activity and whose purpose is to articulate knowledge and to provide the exchange of experiences and knowledge between them.

It is necessary to integrate health and education professionals in these capacities, in addition to analyzing their needs and valuing them in the construction of these proposals. The knowledge of more than one discipline and sector should be considered and encouraged, since they can give resolution to the complex needs of the educational context. This is possible when professionals share assignments in any subject proposed by the School Health Program, where all knowledge is considered.

Other dimensions of the Health in the School Program should also be analyzed in the light of Complexity Theory, in order to understand nuances that are established in the relationships of those involved in this intervention.

\section{REFERENCES}

1. Rosas SR. Systems thinking and complexity: considerations for health promoting schools. Health Promot Int [Internet]. 2017 apr 1; [cited 2019 jan 30]; 32(2):301-11. Available from: https://doi.org/10.1093/heapro/ dav109

2. Turunen $H$, Sormunen M, Jourdan D, Seelen JV, Buijs G. Health Promoting Schools - a complex approach and a major means to health improvement. Health Promot Int [Internet]. 2017 apr 1; [cited 2019 jan 30]; 32(2):177-84. Available from: https://doi.org/10.1093/heapro/dax001

3. Medeiros ER, Rebouças DGC, Paiva ACS, Nascimento CPA, Silva SYB, Pinto EKG. Studies evaluating of health interventions at schools: an integrative literature review. Rev Lat Am Enfermagem [Internet]. 2018 jul 16; [cited 2019 jan 30]; $26:$ e3008. Available from: http://dx.doi. org/10.1590/1518-8345.2463.3008

4. Oliveira FPSL, Vargas AMD, Hartz Z, Dias S, Ferreira EF. Elementary and lower secondary school students' perceptions of the Health at School Programme: a case study in Belo Horizonte, Brazil. Cien Saude Colet [Internet]. 2018 set; [cited 2019 jan 30]; 23(9):2891-8. Available from: http://dx.doi.org/10.1590/1413-81232018239.16582018

5. Machado MFAS, Gubert FA, Meyer APGFV, Sampaio YPCC, Dias MSA, Almeida AMB, et al. The health school programme: a health promotion strategy in primary care in Brazil. Rev Bras Crescimento Desenvolv Hum [Internet]. 2015; [cited 2019 jan 30]; 25(3):307-12. Available from: https://dx.doi.org/10.7322/jhgd.96709

6. Cord D, Gesser M, Nunes ASB, Storti MMT. The Meanings that Professionals who Work in the School Health Program (SHP) Give to Learning Difficulties: Pathologization and Medicalization of School Failure. Psicol Ciênc Prof [Internet]. 2015 jan/mar; [cited 2019 jan 30]; 35(1):40-53. Available from: https://dx.doi.org/10.1590/19823703000952013
7. Chiari APG, Ferreira RC, Akerman M, Amaral JHL, Machado KM, Senna MIB. Inter-sector network in Brazil's School Health Program: subjects, perceptions, and practices. Cad Saude Publica [Internet]. 2018 may 10; [cited 2019 jan 30]; 34(5):e00104217. Available from: http://dx.doi. org/10.1590/0102-311x00104217

8. França T, Medeiros KR, Belisario SA, Garcia AC, Pinto ICM, Castro JL, et al. Continuous Health Education policy in Brazil: the contribution of the Teaching-Service Integration Standing Committees. Cien Saude Colet [Internet]. 2017 jun; [cited 2019 jan 30]; 22(6): 1817-28. Available from: http://dx.doi.org/10.1590/1413-81232017226.30272016

9. Medeiros ER, Pinto ESG, Paiva ACS, Nascimento CPA, Rebouças DGC, Silva SYB. Facilities and difficulties in implementing the Health at School Program in a municipality in northeastern Brazil. Rev Cuid [Internet]. 2018; [cited 2019 jan 30]; 9(2):2127-34. Available from: http:// dx.doi.org/10.15649/cuidarte.v9i2.514

10. Baggio MA, Berres R, Gregolin BPS, Aikes S. Introduction of the School Health Program in the city of Cascavel, Paraná State: report of nurses. Rev Bras Enferm. [Internet]. 2018; [cited 2019 jan 30]; 71(Suppl 4):15407. Available from: $\mathrm{http}: / / \mathrm{dx}$.doi.org/10.1590/0034-7167-2017-0188

11. Ataliba P, Mourão L. Impact Assessment of the Health Program in Schools. Psicol Esc Educ [Internet]. 2018 jan/apr; [cited 2019 jan 30]; 22(1):27-35. Available from: https://dx.doi.org/10.1590/2175-35392018011566

12. Morin E. Introdução ao pensamento complexo. $4^{\mathrm{a}}$ ed. Porto Alegre: Sulina; 2011.

13. Medeiros ER, Pinto ESG. Experience and professional training in the School Health Program. Rev Esc Enferm USP [Internet]. 2018 oct; [cited 2019 jan 30]; 52:e03378. Available from: http://dx.doi.org/10.1590/ s1980-220x2017048603378

14. Dias MSA, Vieira FMBR, Silva LCC, Vasconcelos MIO, Machado MFAS. Inter-professional collaboration in the 'Health and Prevention in Schools' Project. Cien Saude Colet [Internet]. 2016 jun; [cited 2019 jan 30]; 21(6):1789-98. Available from: http://dx.doi.org/10.1590/141381232015216.08112016

15. Leite CT, Machado MFAS, Vieira RP, Marinho MNASB, Monteiro CFS The school health program: teachers' perceptions. Invest Educ Enferm [Internet]. 2015; [cited 2019 jan 30]; 33(2):280-7. Available from: https:// dx.doi.org/10.17533/udea.iee.v33n2a10

16. Carvalho FFB. Health goes to school: health promotion in pedagogical practices. Physis [Internet]. 2015 dec; [cited 2019 jan 30]; 25(4):1207-27. Available from: http://dx.doi.org/10.1590/S0103-73312015000400009

17. Farias DN, Ribeiro KSQS, Anjos UU, Brito GEG (2018). Interdisciplinary and interprofessionality in the Family Health Strategy. Trab Educ Saúde [Internet]. 2018 jan/apr; 16(1):141-62. Available from: https://dx.doi. org/10.1590/1981-7746-sol00098

18. Sousa MC, Esperidião MA, Medina MG. Intersectorality in the 'Health in Schools' Program: an evaluation of the political-management process and working practices. Cien Saude Colet [Internet]. 2017 june; [cited 2019 jan 30]; 22(6):1781-90. Available from: http://dx.doi. org/10.1590/1413-81232017226.24262016

19. Caveião C, Gonçalves AP, Gilaberte B, Sales WB, Dezoti AP, Oliveira VBCA. Knowledge of nurses who working in basic health care on attributions and guidelines of the health program in the school. Rev Eletrônica Acervo Saúde [Internet]. 2018 feb; [cited 2019 jan 30]; 10(2):1574-80. Available from: https://doi.org/10.25248/reas190_2018

20. Peruzzo HE, Bega AG, Lopes APAT, Haddad MCFL, Peres AM, Marcon SS. The challenges of teamwork in the family health strategy. Esc Anna Nery Rev Enferm [Internet]. 2018 aug 2; [cited 2019 jan 30]; 22(4):e20170372. Available from: http://dx.doi.org/10.1590/2177-9465-ean-2017-0372

21. Morin E. A religação dos saberes: o desafio do século XXI. $1^{\text {a }}$ ed. Rio de Janeiro: Bertrand Brasil; 2012. 